\title{
REVIEW
}

\section{Escaped farmed salmon and trout in Chile: incidence, impacts, and the need for an ecosystem view}

\author{
Maritza Sepúlveda ${ }^{1, *}$, Ivan Arismendi ${ }^{2}$, Doris Soto ${ }^{3}$, Fernando Jara ${ }^{4}$, \\ Francisca Farias ${ }^{5}$
}

${ }^{1}$ Centro de Investigación y Gestión de los Recursos Naturales (CIGREN), Instituto de Biología, Facultad de Ciencias, Universidad de Valparaíso, Gran Bretaña 1111, Playa Ancha, Valparaíso, Chile

${ }^{2}$ Department of Fisheries and Wildlife, Oregon State University, Nash Hall, Room 104, Corvallis, Oregon 97331, USA

${ }^{3}$ Aquaculture Management and Conservation Service (FIMA), Fisheries and Aquaculture Department, FAO of UN, Via delle Terme di Caracalla, 00153 Rome, Italy

${ }^{4}$ Statistics and Information Service (FIPS), Fisheries and Aquaculture Department, FAO of UN, Via delle Terme di Caracalla, 00153 Rome, Italy

${ }^{5}$ Oficina OCDE y Foros Internacionales, Ministerio del Medio Ambiente, Teatinos 258, Santiago, Chile

\begin{abstract}
The exponential growth of the salmonid farming industry during the last 3 decades has created conditions for massive escapes of these exotic species into natural environments in southern Chile. Here, we review and update information about salmonid escapes from 1993 to 2012 and examine their potential environmental, social, and economic consequences. We estimate that more than 1 million salmonids escape each year from marine farms, mainly due to weather conditions and technical and operational failures of net-pens. While a decrease in the magnitude of escaped Atlantic and coho salmon has occurred during the last several years, escaped rainbow trout have not followed the same pattern. Rainbow trout have become a greater threat to native ecosystems due to their greater potential to establish self-sustaining naturalized populations. The main ecological effects of escapees are related to short-term predatory effects upon native fish, long-term effects linked to the likelihood of farmed salmon establishing self-sustainable populations, and disease and pathogen transfer to native fauna. More research is needed to identify and develop reliable indicators to estimate the impact of escapees at the ecosystem level in both marine and freshwater systems. An understanding of the mechanisms of coexistence between native fishes and introduced non-native salmonids may be useful to design effective management strategies aimed at protecting native fish from salmonid introductions. A precautionary approach that encourages local artisanal and recreational fisheries to counteract colonization and naturalization of salmon species in southern Chile may constitute another management option.
\end{abstract}

KEY WORDS: Fish farming · Salmo salar · Oncorhynchus kisutch · Oncorhynchus mykiss • Exotic species

\section{INTRODUCTION}

Farming of salmon and trout (hereafter salmonids) has experienced an exponential growth during recent decades, with Chile and Norway accounting for over $80 \%$ of the global salmonid aquaculture pro-

*Email: maritza.sepulveda@uv.cl duction (Fig. 1; FAO 2011). In 2006, Chilean salmonid aquaculture reached its highest production, with nearly $640000 \mathrm{t}$ valued at US $\$ 3.8$ billion (FAO 2011). This production corresponded mostly to Atlantic salmon Salmo salar (60.3\%), coho salmon Oncorhynchus kisutch $(17.5 \%)$, and rainbow trout O. mykiss

(C) The authors 2013. Open Access under Creative Commons by Attribution Licence. Use, distribution and reproduction are unrestricted. Authors and original publication must be credited. 


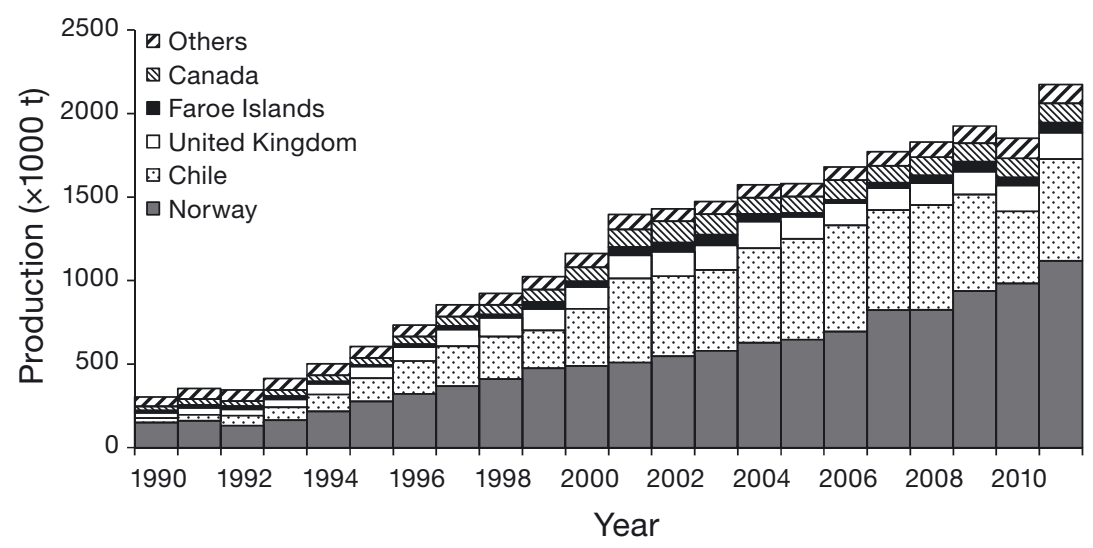

Fig. 1. Oncorhynchus mykiss, O. kisutch, and Salmo salar. World production (thousands of tonnes) of salmonid species including rainbow trout and coho and Atlantic salmon between 1990 and 2011 (main producers are shown).

Source: FAO aquaculture statistics (www.fao.org/fishery/statistics/en)
1993 to 2012, and examine their potential environmental and economic consequences. We also provide a summary of the main factors that influence escapees, and discuss mitigation and prevention alternatives. We propose actions to diminish escape risks and highlight some management practices to mitigate negative impacts and enhance those which appear to be positive. This information is fundamental to understand the trade-off between the negative effects of biological invasions upon natural ecosystems and the high economic value of salmonids for aquaculture and recreational purposes in Chile and elsewhere.
$(22.2 \%)$. Salmonids were initially introduced in the Southern Hemisphere for recreational purposes in the early 1900s (e.g. rainbow trout and brown trout $S$. trutta), and additional introductions (mostly Pacific salmon species) occurred during the 1970s when they were farmed in hatcheries for ranching and aquaculture-fishery purposes (Basulto 2003). The expansion of the aquaculture industry in Chile began in the 1980s with salmonids grown to commercial size in net-pens in the inner seas and fjords of the Chiloe Archipelago in the Lakes Region (41-43 ${ }^{\circ}$; Fig. 2). Currently the aquaculture industry, both in size and in the number of farming facilities (>1150), is rapidly expanding farther south (Aysen Region; 44-46 $\mathrm{S}$; Fig. 2) (Buschmann et al. 2009, Niklitschek et al. 2013).

Salmonid farming phases mirror the cycles used by salmonids during their natural lives. Salmonids inhabit both fresh and marine waters, with freshwater systems playing a key role during early developmental stages. In Chile, the main growth of stocks takes place in the sea (Soto et al. 2001, Rojas \& Wadsworth 2007) where they are reared in either square or circular floating net-pens until they attain commercial size (at 1-3 yr of age). The current density of salmonids in each net-pen is 16 to $20 \mathrm{~kg} \mathrm{~m}^{-3}$, although higher densities $\left(\sim 30 \mathrm{~kg} \mathrm{~m}^{-3}\right)$ were recorded in some facilities before 2008 (X. Rojas pers. comm.). It has been shown that as the magnitude and number of sites where salmonid farming occurs increases, the potential consequences due to net-pen or farm failure increase, resulting in a higher probability of exotic escapees in the environment (Arismendi et al. 2009, Jensen et al. 2010, Niklitschek et al. 2013).

Here, we review and update information about salmonid escapes in Chile during the period from

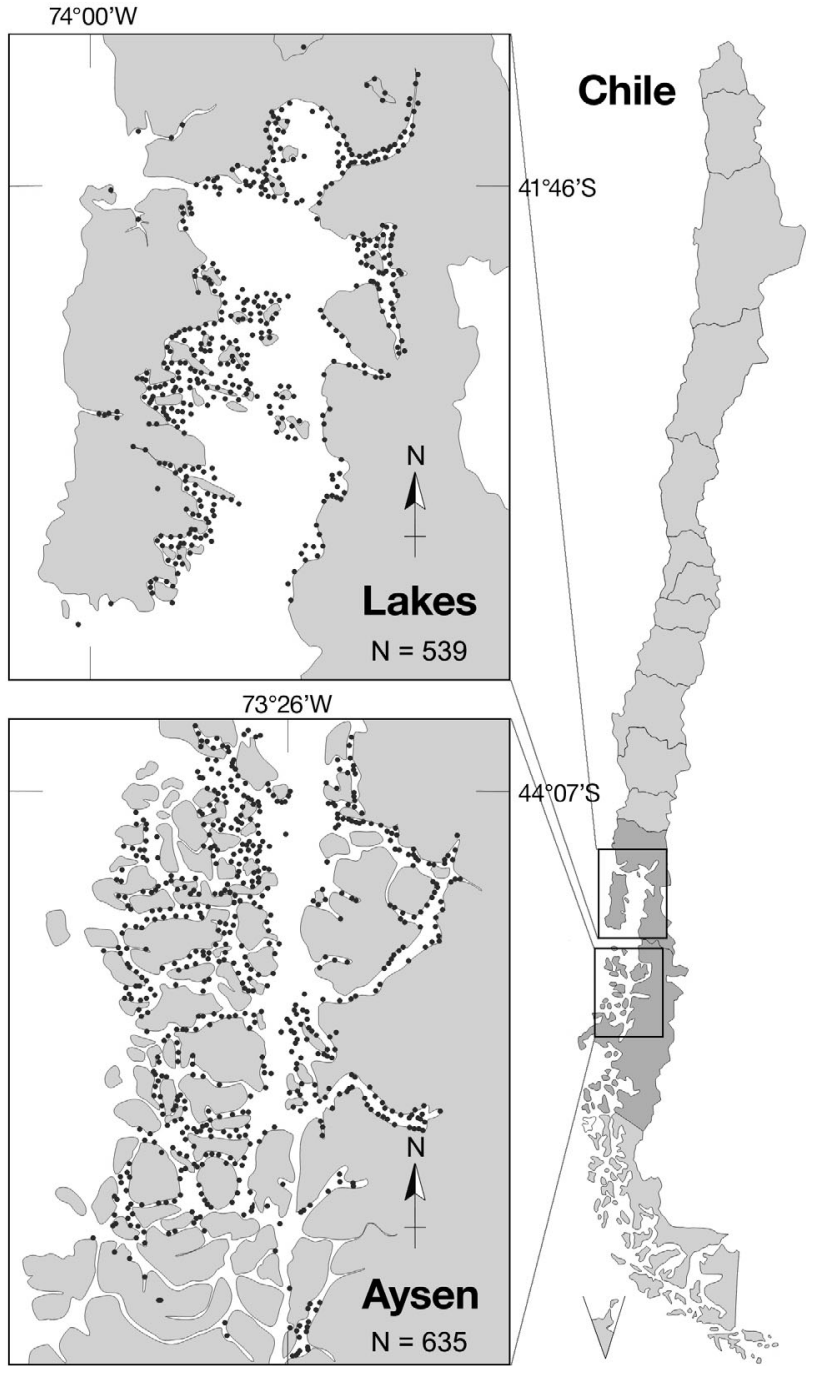

Fig. 2. Salmonid farm locations (black dots) in the Lakes and Aysen regions of Chile 


\section{CAUSES OF SALMONID ESCAPES}

Several factors can explain the escapes of salmonids from facilities in coastal, marine, and freshwater environments, including those of external and internal origins. Among these, external factors include attacks by predators (e.g. Sepúlveda \& Oliva 2005, Vilata et al. 2010), theft or vandalism (intentional damage of nets to let salmon escape and then steal the fish), and adverse weather conditions, whereas internal factors are directly related to and under the responsibility of the fish farmer and include failure or neglect during routine fish handling procedures and site maintenance as well as accidental boat collisions (Sepúlveda et al. 2009). Reports by salmonid farm companies during the period 2004 to 2009 indicate that, considering both regions together, escape events were primarily caused by severe weather conditions $(29 \%)$, theft $(21 \%)$, and structural failure of netpens and deficient handling incidents $(18 \%$; Fig. 3). Storms lead to stronger waves and currents, resulting in ripping of the net-pen tethering ropes, breaking of the net-pen mesh, or tipping over of the net-pens (Jensen et al. 2010). Unfortunately, due to the high demand for new farming sites, often the selection of a new location does not include proper consideration of potentially adverse environmental conditions (i.e. water currents, winds), increasing the risk of fish escapes during extreme adverse weather conditions. Overall, the causes of salmonid escapes are similar to those reported by producers in other salmonidproducing countries such as Norway, Canada, and Scotland (Thorstad et al. 2008), but there the responsibility for fish escapes lies mainly with the farmer

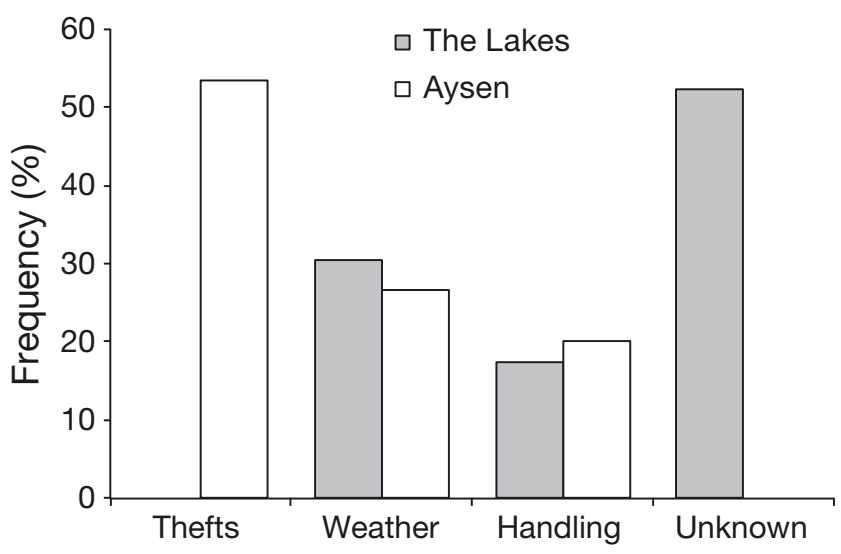

Fig. 3. Main technical issues associated with salmonid escapes, according to reports by salmonid farm companies in the Lakes (filled bars) and Aysen (open bars) regions of Chile (see Fig. 2) during the period 2004 to 2009. Source: National

Fisheries Services and Chilean Navy (unpubl. data) and/or providers of the equipment and services, including routine site maintenance and fish handling (Melo et al. 2005). Routine net-pen maintenance and fish handling procedures carried out at the farms also pose escape risks, from holes in the nets or transportation of fish among cages. Moreover, carelessness when changing fish or predator nets may result in the escape of fish. The sorting of fish into 2 or more netpens through a tube can also lead to the involuntary release of species if the tube is poorly mounted. Moreover, collisions from boats used during operational activities, predator attacks (e.g. sea lions and birds), inadequate manufacturing materials, and poor net maintenance increase the probability of escapes (Robles 2002). Lastly, although it is difficult to quantify, intentional damage of nets attributable to fishermen or farmers seeking to benefit from the subsequent captures of escaped salmonids or insurance policies are also factors that may increase escape risks.

\section{QUANTIFYING SALMON AND TROUT ESCAPES}

The real magnitude of salmonid escapes is most likely underestimated, mainly due to the fact that not all escapes are detected or reported. Numbers of escaped salmonids in Chile have mostly been reported or estimated after large and/or catastrophic events (Soto et al. 2001, Thorstad et al. 2008, Niklitschek et al. 2013). In addition to escapes caused by harsh weather conditions, farmed salmon may escape from marine net-pens through persistent lowlevel leakage (Buschmann et al. 2009, Schröder \& García de Leaniz 2011). Unfortunately, information on the number of salmonids that escape from regular leakages in Chile remains poorly documented. Soto et al. (2001) estimated that 1 to $5 \%$ of escapees come from leakages. However, this estimate has not been evaluated directly and remains somewhat speculative, as the threat of leakages remains insufficiently recognized (Sepúlveda et al. 2009).

By consulting insurance companies, Soto et al. (2001) reported an important number of escapes after major storms during 1994 and 1995 (Fig. 4, Table 1). Since 2004, the salmon industry in Chile must inform government institutions about every escape event at their facility, but there are no official records of escapes available for the period 1997 to 2003. A total of 58 escape events were reported during the period 2004 to 2012 (data from Soto et al. 1997 and from the National Fisheries Service; Fig. 4), accounting for almost 6.5 million salmonid escapees, although it is estimated that more than 1 million salmonids may 
escape each year in Chilean marine systems (Thorstad et al. 2008).

During the 13 years for which escape reports are available (1993 to 1996 and 2004 to 2012) a total of 3.7 million Atlantic salmon $\left(289600 \mathrm{yr}^{-1}\right), 3.1$ million coho salmon $\left(239954 \mathrm{yr}^{-1}\right)$, and 4.0 million rainbow trout (313892 $\left.\mathrm{yr}^{-1}\right)$ were reported to have escaped from salmon farms located in both the Lakes and Aysen regions. These amounts of escaped salmonids appear to be similar to those reported in other countries such as Norway and Scotland (440000 and $216000 \mathrm{yr}^{-1}$, respectively; Thorstad et al. 2008, Jensen et al. 2010) and within an estimated range of escapes in Chile (1 to $2 \%$ of the total production; Niklitschek et al. 2006). However, when considering total salmonid production, the proportion of escaped fish in Chile was double that of Norway and similar to that of Scotland.

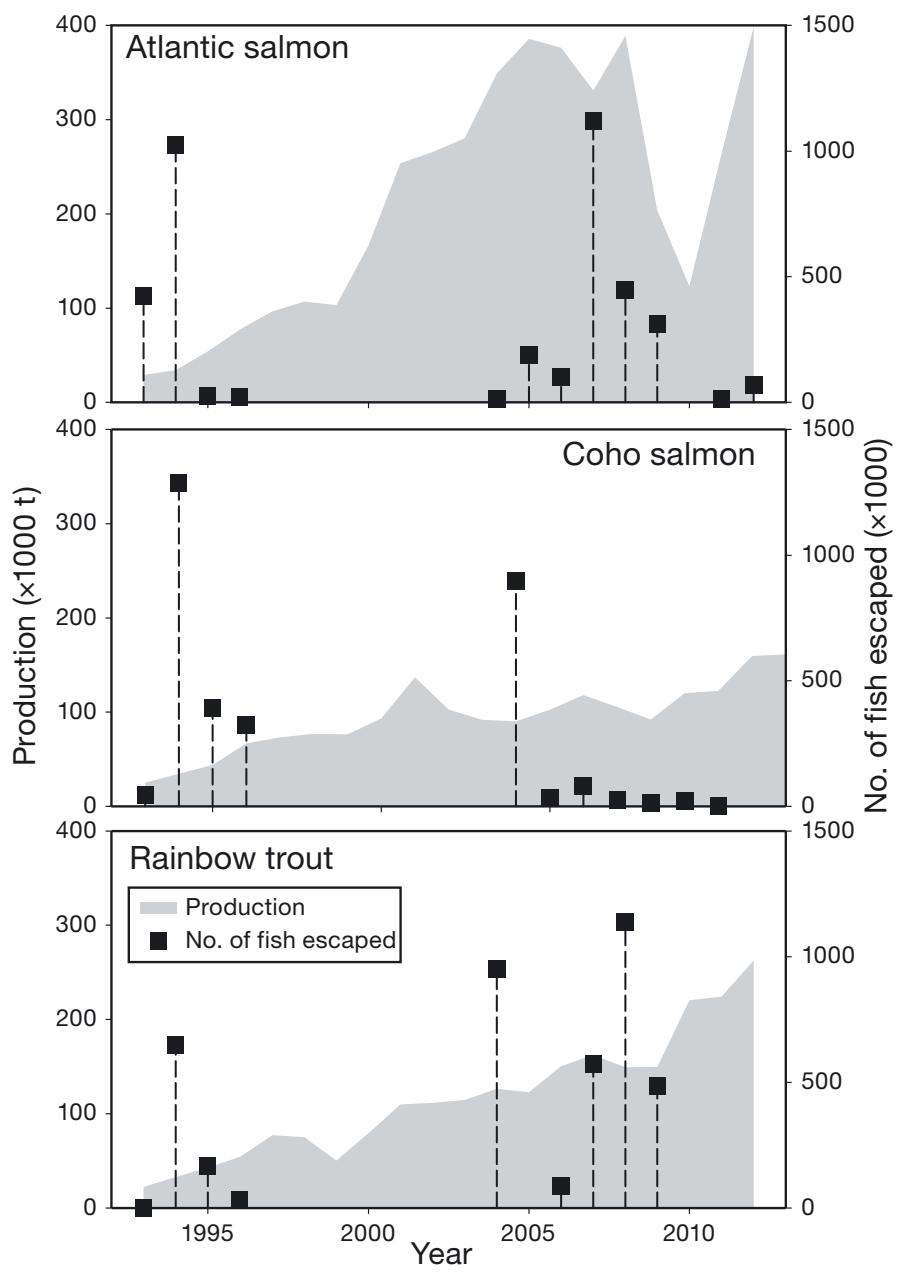

Fig. 4. Total salmonid production and reported escapes. Escape data for 1993 to 1996 from Soto et al. (1997) and for 2004 to 2012 from the National Fisheries Service (unpubl. information). Production data for 1993 to 2012 from FAO aquaculture statistics (www.fao.org/fishery/statistics/en)
Overall, the number of salmon and trout reported to escape relative to the total production varies greatly among the 3 species analyzed; it was lowest for Atlantic salmon and highest for coho salmon and rainbow trout. The average escape proportions (i.e. total no. of escaped fish reported divided by the total no. of fish produced, by species) covering both the 1993 to 1996 and 2004 to 2012 period were $1.2 \mathrm{t}$ for Atlantic salmon, $2.4 \mathrm{t}$ for rainbow trout, and $2.5 \mathrm{t}$ for coho salmon. Comparing the 2 time periods (1993-1996 versus 2004-2012), the escapes of Atlantic salmon and coho salmon decreased in the second period (Atlantic salmon: from 374349 to $251933 \mathrm{yr}^{-1}$; coho salmon: from 512413 to $118860 \mathrm{yr}^{-1}$ ) despite a marked increase in production during the second period, especially for Atlantic salmon. In contrast, the escapes of rainbow trout increased during the second time period (from 211669 to $359324 \mathrm{yr}^{-1}$ ). This tendency in rainbow trout escapes is likely due to largescale escape events in the Aysen Region during 2004, 2007, and 2008. The largest escape event in 2004 corresponded to a specific incident when about 1.8 million rainbow trout and coho salmon escaped due to bad weather conditions. The largest event in 2007 was mainly associated with the tsunami that took place in April, when more than 1.5 million specimens were reported as escaped from net-pens. For 2008, Thorstad et al. (2008) estimated that about 5 million specimens had escaped, which could account for one of the largest escape events documented both at national and international levels.

In freshwater systems, the information regarding salmon escapes is even more scarce, with a total of 11 events reported from 2004 to 2012 accounting for a total of 613586 salmonid escapees, principally from lakes (75\% rainbow trout and $25 \%$ Atlantic salmon). A positive and strong relationship between the magnitude of salmon production in freshwater facilities and the relative abundance of free-living salmonids including coho, Atlantic, rainbow trout, and Chinook salmon has been described in lakes of southern Chile (Arismendi et al. 2009, Young et al. 2009, 2010, García de Leaniz et al. 2010, Vanhaecke et al. 2012a). In fact, exotic salmonids have been reported as the most abundant fishes in freshwater systems of Chile (Soto et al. 2006). Since there is no documented evidence of successful natural reproduction of Atlantic and coho salmon in Chile, individuals from these species inhabiting freshwater systems appear to have exclusively originated from aquaculture escapes (Soto et al. 2001, 2006, Arismendi et al. 2009, Schröder \& García de Leaniz 2011). Also, because no massive escape events have been reported in freshwater systems, the 
Table 1. Salmo salar, Oncorhynchus kisutch, and O. mykiss. Total salmonid production and reported escapes by species from 1993 to 2012. Escape data for 1993 to 1996 from Soto et al. (1997) and for 2004 to 2012 from the National Fisheries Service (unpubl. information). Production data for 1993 to 2012 from FAO aquaculture statistics (www.fao.org/fishery/statistics/en)

\begin{tabular}{|c|c|c|c|c|c|c|c|c|}
\hline \multirow[t]{2}{*}{ Year } & \multicolumn{4}{|c|}{ - Production $(\times 1000 t)$} & \multicolumn{4}{|c|}{ - Number of fish escaped $(\times 1000)$} \\
\hline & S. salar & O. kisutch & O. mykiss & Total & S. salar & O. kisutch & O. mykiss & Total \\
\hline 1993 & 29.2 & 25.2 & 22.3 & 76.6 & 425.0 & 43.8 & 0 & 468.8 \\
\hline 1994 & 34.2 & 34.5 & 32.9 & 101.6 & 1023.1 & 1288.8 & 646.4 & 2958.3 \\
\hline 1995 & 54.3 & 44.0 & 42.7 & 141.0 & 27.4 & 392.1 & 168.5 & 588.0 \\
\hline 1996 & 77.3 & 67.0 & 54.4 & 198.7 & 21.9 & 324.9 & 31.8 & 378.6 \\
\hline 1997 & 96.7 & 73.4 & 77.1 & 247.2 & - & - & - & - \\
\hline 1998 & 107.1 & 76.9 & 75.1 & 259.1 & - & - & - & - \\
\hline 1999 & 103.2 & 76.3 & 50.4 & 229.9 & - & - & - & - \\
\hline 2000 & 166.9 & 93.4 & 79.6 & 339.9 & - & - & - & - \\
\hline 2001 & 253.9 & 136.9 & 109.9 & 500.7 & - & - & - & - \\
\hline 2002 & 265.7 & 102.5 & 111.7 & 479.9 & - & - & - & - \\
\hline 2003 & 280.3 & 91.8 & 114.6 & 486.7 & - & - & - & - \\
\hline 2004 & 349.1 & 90.3 & 126.6 & 566.0 & 12.4 & 896.5 & 949.5 & 1857.4 \\
\hline 2005 & 385.8 & 102.5 & 123.0 & 611.3 & 190.3 & 31.4 & - & 221.7 \\
\hline 2006 & 376.5 & 118.2 & 150.6 & 645.3 & 95.8 & 80.0 & 89.1 & 268.9 \\
\hline 2007 & 331.0 & 105.5 & 162.4 & 598.9 & 1119.2 & 26.3 & 573.6 & 1719.1 \\
\hline 2008 & 388.8 & 92.3 & 149.4 & 630.5 & 447.4 & 12.9 & 1137.1 & 1597.4 \\
\hline 2009 & 204.0 & 120.0 & 149.6 & 473.6 & 312.0 & 22.3 & 484.7 & 819.0 \\
\hline 2010 & 123.2 & 122.7 & 220.2 & 466.1 & - & 0.4 & - & 0.4 \\
\hline 2011 & 264.4 & 159.6 & 224.5 & 648.5 & 15.5 & - & - & 15.5 \\
\hline 2012 & 398.3 & 161.3 & 262.7 & 822.3 & 70.9 & - & - & 70.9 \\
\hline
\end{tabular}

recurrent presence of salmonids in freshwater systems could be explained by frequent operational leakages from salmon farms.

\section{ECOLOGICAL CONSEQUENCES OF ESCAPES}

There is a general consensus among scientists that introduced species directly or indirectly alter the structure and diversity of natural ecosystems (Grosholz 2002, Naylor et al. 2005). Among freshwater introductions, salmonids are considered to be among the most pervasive exotic species in the world (Pascual et al. 2009). In Chile, the environmental concerns from salmonid escapes have focused on shortterm predatory effects upon native fish, long-term effects linked to the probability of farmed salmon establishing self-sustainable populations, and disease and pathogen transfer (Young et al. 2010, Arismendi et al. 2012, Niklitschek et al. 2013).

\section{Displacement of native fishes due to ecological interactions}

Freshwater systems, including rivers and lakes, and marine systems have been invaded by salmonids, and it is possible that their ecosystem-level pro- cesses may be affected through trophic cascade effects (Carpenter et al. 1996). Unfortunately, there is scarce information about the state of native fishes before salmonid introductions, which makes an understanding of their impacts more difficult to obtain (García de Leaniz et al. 2010). Based on stomach and stable isotope analyses, several studies conducted in Chile have shown negative effects from salmonid species on native fishes due to predatory and interference competition (Soto et al. 2001, 2006, Arismendi et al. 2009, 2012, Penaluna et al. 2009, Young et al. 2009, 2010, García de Leaniz et al. 2010). Collectively, the evidence suggests that salmonid species have detrimental impacts on native fishes in all types of ecosystems, including lakes (Soto et al. 2006, Arismendi et al. 2009, García de Leaniz et al. 2010, Habit et al. 2010, Correa \& Hendry 2012), rivers (Soto et al. 2006, Penaluna et al. 2009, Arismendi et al. 2012, Vanhaecke et al. 2012a,b), and inner seas (Soto et al. 2001). Lakes in particular, where most of the freshwater phase of salmonid aquaculture occurs, could be particularly sensitive to the impacts of escapes because top predator species may produce a detrimental impact to aquatic biodiversity and species richness (Moyle \& Light 1996, García de Leaniz et al. 2010, Vanhaecke et al. 2012a,b). However, a more complete evaluation of the effects of predation and competition on native fauna is prevented by the 
fact that the basic biology and ecology of native aquatic communities in freshwater, inner seas, and fjords of southern Chile remains poorly understood.

\section{Spreading of pathogens and diseases}

Animal health, especially in response to disease, is another issue to consider when discussing the ecological impacts of salmonid escapes, because exotic salmonids can introduce new pathogens, alter disease patterns, and even act synergistically to increase the impact of other stressors (García de Leaniz et al. 2010, Habit et al. 2010). During the past few years, several aquaculture facilities have been affected by epidemic outbreaks of diseases, favored by the conditions of fish being confined at high densities and the short distance among farms (Asche et al. 2010). In addition, escaped salmonids can travel large distances (Melo et al. 2005, Whoriskey et al. 2006, Skilbrei et al. 2009), and hence they become potential vectors for parasites and diseases at a broad scale (Thorstad et al. 2008). Epidemiological studies conducted in the Northern Hemisphere (i.e. Ireland, Scotland, Norway, and Canada) suggest that the occurrence of diseases such as rickettsial septicemia and sea lice (Caligus spp.) in both salmonids and native fishes are directly related to higher concentrations of farmed fishes (Krkosek et al. 2005, Naylor et al. 2005). Also, a virus that regularly affects salmon farms in different countries including Chile is the infectious pancreatic necrosis virus, which has been detected in all salmon species at all developmental stages (freshwater and ocean phase of aquaculture) as well as in native fishes, mollusks, and crustaceans (Rodríguez Saint Jean et al. 2003, Asche et al. 2010). The infectious salmon anemia virus has also been documented in salmon farms in Norway, Canada, Scotland, the USA, and recently in Chile, causing enormous damage to the industry and the local and national economy (Niklitschek et al. 2013). In Chile, the potential transmission of diseases from farmed salmonids to other taxa such as marine birds and mammals is yet unknown. However, preliminary evidence of skin lesions in dolphins has suggested a potential link to the salmonid aquaculture industry (S. Heinrich pers. comm.).

\section{Threats from escapees establishing self-sustaining populations}

Rainbow trout and Chinook salmon escapees may pose the greatest threat to native ecosystems be- cause they have a greater potential to establish naturalized populations compared to both Atlantic and coho salmon. Thus, the magnitude of their ecological impacts may increase when they can establish selfsustaining populations (Soto et al. 2006, 2007, Correa \& Gross 2008, Arismendi et al. 2009, 2011a,b). The successful establishment of self-sustainable populations could be related to a relatively high plasticity of these species (i.e. the ability to feed on a broad range of organisms; Becker et al. 2007). Coho, Chinook salmon, and rainbow trout have also been part of ranching programs in the past which eventually may also play a role in their establishment, especially in the case of Chinook salmon (Astorga et al. 2008). It is also possible that salmonid escapees might increase the probability of establishing self-sustaining populations when those escapes are greater than from slow leakages or 'silent' escapes (Consuegra et al. 2011). According to Consuegra et al. (2011), invasion success may also depend on propagule pressure. For example, rainbow trout may have achieved high establishment success and expanded more rapidly than other anadromous species (such as brown trout) because their spread is aided by rainbow trout escaped from fish farms (Ciancio et al. 2008).

For Atlantic salmon, there is no evidence for the establishment of naturalized populations (Soto et al. 2001, 2006, Schröder \& García de Leaniz 2011). Indirect evidence suggests that this species fails to establish because escaped individuals do not feed or grow very well in the wild (Soto et al. 2001). This is similar to other systems where efforts to establish Atlantic salmon as a game fish species have failed (Naylor et al. 2005). Considering that Atlantic salmon have traditionally represented the highest proportion of farmed salmonids in Chile, the risk of establishment is an ongoing, unresolved question. Similarly to Atlantic salmon, there is no evidence suggesting that coho salmon may successfully reproduce in the Aysen Region, although some evidence of reproductive individuals migrating upstream has been reported (Becker et al. 2007, Soto et al. 2007). Hence, the possibilities for management and mitigation of any adverse effects of escapes in these species may be greater than for the other salmonids.

\section{SOCIAL AND ECONOMIC EFFECTS OF ESCAPES}

The conflict between the salmon industry and the artisanal fishing sector is one of the most relevant socio-economical impacts arising from salmon escapes in Chile. Small-scale fishing of escaped 
salmon could have an important social and economic effect, providing food security and extra income for rural people and low-income families (Arismendi 1997, Soto et al. 2001). For example, during the massive escapes of 1994-95 a large number of local fishers, often women and children, were fishing for salmonids (mostly with gillnets), which were then sold in local markets (Soto et al. 2001). The practice is still quite common in communities near salmon farming locations in the inland seas and lakes. It is important to note, however, that the application of large quantities of antibiotics in the salmon aquaculture in Chile has environmental implications that potentially impact the health of humans and wildlife (Fortt et al. 1997).

Currently salmonids are the property of farm owners even after they have escaped, so the capture and marketing of escaped salmon by artisanal fishermen is considered an illegal practice. During the previously mentioned massive escapes, fishermen created considerable turmoil requesting fishing rights to these escaped salmon, in addition to claiming that native fish resources were affected (Soto et al. 2001). The possibility of an artisanal fishery is somewhat feared by salmon farmers, as legalization of a salmon fishery could generate competing products whose standards may not be at the level of those adopted by the farmers' organizations (Niklitschek et al. 2013). It is clear however, that products from the salmon fishery could be oriented to local markets for domestic consumption, whereas production from salmon aquaculture is aimed for export to international markets. However, for salmon farmers, opening a fishery of escaped salmon could enhance vandalism and/or theft at the farms. If some of the escaped salmon species are indeed able to develop and establish naturalized populations, we predict a new 'battleground' in the marine environment between artisanal fishery and salmon farming.

In addition, sport fishing entities are debating the pros and cons of this new species for tourism and business. Hence this creates conflict between those who want to fish and those who would like to eliminate these returning exotic salmon runs.

\section{PREVENTION AND MITIGATION OF ESCAPES}

\section{Preventing salmonid escapes}

Considering that many escapes are due to human mistakes, preventive measures can be effective in a number of cases. A prevention system utilized in aquaculture facilities located in streams is the use of physical barriers to prevent fish from escaping. The barriers are strategically located in critical connection points throughout the facilities, such as pools or tanks containing the fish in water inlets and outflows. Some companies have more efficient systems that minimize the risk of escapes by using recirculation tanks. In these closed and independent systems, salmonids do not come into contact with the outside environment.

Ocean grow-out farms pose the largest challenges for the industry. Although anti-predator nets protect against external attacks and may also serve as containment when fish nets tear, there are no actual physical barriers in place. Instead, fish farmers have developed maintenance practices to prevent nets from breaking and releasing fish into the environment. The proper tension of fish and anti-predator nets through anchoring and mooring systems reduces friction between materials and prevents nets from sticking to one another, thereby preventing sea lions from approaching the fish. Other typical practices to reduce escape risks include replacing and maintaining nets and monitoring by divers or the use of video cameras.

\section{Mitigating salmonid escapes}

The aquaculture regulatory framework in Chile includes environmental regulations (the Environmental Impacts Assessment System, SEIA) established in 1997, and the executive decree on environmental norms for aquaculture (RAMA). These regulatory tools and their operational norms affect both licensing and operation of fish farms. The SEIA includes the establishment of contingency plans for escaped salmonids and, according to the RAMA, these plans must follow special guidelines. These guidelines have information about operational procedures and devices to recover escaped salmonids, as well as the obligation to provide immediate detailed information to authorities about escapees. Mandatory reporting of escape incidents was introduced to Chile in 2001, with a national statistics database since 2004. This has enabled a gross assessment of the overall status of the escape problem at an industry-wide scale from year to year, and an evaluation of the causes of escapes.

Different and non-exclusive techniques are used to capture free-living salmonids that have escaped from marine grow-out farms. The most popular technique is to try to capture the escaped salmonids with nets 
or mobile empty cages, often using pellets to attract escaped salmonids to a particular location (Melo et al. 2005). All aquaculture staff is required to work following an escape event, but often the employees do not have training in how to manage or respond to such events.

No quantitative information is available on how effective these prevention techniques and recapture systems are. The background information collected in other producer countries reveals a low success rate for recapture efforts (recaptures amount to $<3 \%$; Thorstad et al. 2008). This is likely the case in Chile, because current recapture systems reflect mitigation measures taken by the industry which are both inefficient and insufficient (Melo et al. 2005). The RAMA does not detail specific mitigation and recapture protocols, and producers have to define their own action plan to deal with escaped fish. According to Melo et al. (2005), salmonids do not remain in the vicinity of the cages but are actually highly mobile and can move up to $3 \mathrm{~km}$ in $10 \mathrm{~h}$. In fact, molecular analyses on rainbow trout indicated that the incidence of escapees is widespread (Consuegra et al. 2011). Because large-scale escape events often occur under bad weather conditions, time becomes a critical factor and recapture tasks are extremely complex, which further reduces the success of such operations. Additionally, action plans are not always enforced because of the limited capacity of local and regional government institutions. An improved knowledge of patterns of movements, behavior, and survival rates of escapees would be useful to inform natural resource managers and the fish farming industry.

To reinforce action plans and also regulation by government institutions, it would be useful to determine the specific origin of escaped salmon. Recently, some tools have been developed to differentiate potentially escaped from free-living fish, including the detection of manganese concentration from scales (Adey et al. 2009) and stable isotopes of carbon and nitrogen (Schröder \& García de Leaniz 2011). Furthermore, some approaches with molecular markers have been used in Chile to distinguish whether salmonids in rivers and lakes are descended from specimens introduced for ranching or from individuals which have escaped from salmon farms (Astorga et al. 2008), or whether a genetic admixture occurs between individuals escaping from fish farms and 'naturalized' salmonids (Consuegra et al. 2011). Using this approach as a baseline, in the future it might be possible for each aquaculture facility to have a unique and registered genetic marker stored in a database, allowing a posterior cross-comparison with escaped fish and thus allowing the determination of their specific origin.

Soto et al. (2001) proposed that a mitigation procedure could be that artisanal fishers try to control escaped salmonids by capturing escapees, especially considering that artisanal fishing commonly occurs around fish farm locations. In addition, there is potential for developing a recreational fishery especially following an escape (Arismendi \& Nahuelhual 2007). Such fish could be allowed in a take quota (assuming that the fish are safe to eat), complementing the current catch and release approach for trout. Sport fishing could be improved and facilitated around farms to collect and control escaped fish and to provide additional income to local people and fishermen. It is clear that such a fishery must be well organized to be sure it does not conflict with the industry and/or facilitate more escapes. The promotion of both artisanal and recreational fisheries should be considered only as a mitigation procedure. Although all species of salmonids introduced for aquaculture purposes are already present in both freshwater and marine environments, some of them are not yet reproducing on their own (Soto et al. 2001, 2006, Arismendi et al. 2009). The removal of these potential new invasive species through a salmonid-based fishery could certainly decrease the likelihood of new establishments. Artisanal fisheries based on salmonids should be of limited access and highly regulated in order to discourage the promotion of further releases.

It is important that artisanal and recreational fisheries should not impact native species. Fortunately, in freshwater systems of southern Chile there are no native fish that could be potentially affected by artisanal or recreational fisheries. Native fish are smaller in size than salmonids and thus have a low potential for incidental capture. In general, salmonid-based artisanal fisheries use gillnets, which are highly sizeselective. Anglers tend to use a catch-release approach, avoiding negative effects on native fish. In marine environments, however, the potential for incidental capture of native species is greater than in freshwater, but these native fish already have preexisting historical fisheries and thus an established commercial value (Soto et al. 2001).

Local and regional natural resource managers should be involved to assess free-living and selfsustaining salmonid populations, and should begin discussions with interest groups on the use and management of such populations. To inform these managers, investigators need to evaluate social and economic scenarios involving these potential fisheries. If a monetary value is given to these escaped salmo- 
nids, then the industry could be held accountable to compensate the local and regional governments.

\section{RESEARCH NEEDS}

As has been identified in this review, there are still several gaps in the knowledge of the impacts and consequences of escaped salmonids in Chile. Thus, considering that salmonid aquaculture is expected to continue to grow, different research needs should be identified including biological, social, and economic aspects that could generate useful information for decision makers. One of the most important research needs is to implement a monitoring program to evaluate the frequency, abundance and impact of escaped salmonids. For example, the establishment of long-term field surveys would allow estimation of the relative importance of escaped and selfsustaining salmonid populations. It is also important to evaluate and develop reliable indicators to estimate their impact on native species and ecosystems, as well as their social and economic impact in both marine and freshwater ecosystems (Velásquez et al. 2011). For example, to test broad-scale hypotheses about taxonomic homogenization and expansion of introduced species, a paired comparison between historical and current presence/absence of both native and introduced species appears to be a useful tool (Marr et al. 2010, 2013).

While additional work is needed to increase our knowledge of the processes underlying the patterns described in this review, more data could improve management of non-native salmonids in areas where they impact native fishes negatively. For example, patterns of apparent coexistence of non-native trout and native fishes in some streams could provide clues for managing invasions in more heavily impacted streams (see conservation status in Campos et al. 1998, Habit et al. 2006). Thus, understanding mechanisms of coexistence between native fishes and introduced non-native salmonids may help in designing effective management strategies that protect both native fishes and important recreational fisheries. Coexistence may also improve our knowledge of the functioning of pelagic and benthic communities in lakes and inner seas of southern Chile, maintaining areas without salmonid farming as reference sites to understand more completely the effects of free-ranging salmonids. Even more important is to monitor lakes without salmon farming, especially lakes without trout, which seem to be very scarce (Soto et al. 2006, Correa \& Hendry 2012).

\section{CONCLUSIONS}

Aquaculture is continuing to grow and expand worldwide, as is salmonid farming probably everywhere, including the major producing countries such as Norway and Chile. Effects of escaped salmonids in regions where they are not native are quite different from where they are native such as Norway, because there, major impacts are related to genetic modification of natural populations of Atlantic salmon (Fleming et al. 2000, Thorstad et al. 2008). In Chile, the effects are mostly related to direct impacts of escaped individuals on native fishes and the local environment, including important social and economic effects related to artisanal and recreational fisheries. The establishment of new salmonid species such as Atlantic and coho salmon, with their potential long-term effects due to naturalized populations, requires urgent action by decision makers.

In such a complex situation, with ecological, social, health-related, political, and economic implications, all stakeholders must assume their responsibilities. Government agencies must ensure the ecological balance of water systems, minimum escape levels and effective mitigation measures, including regulations to help manage these values. Salmonid farmers must undertake a more proactive prevention role, which includes (1) identifing critical issues in every stage of salmon farming, so as to establish protocols to prevent salmon escapes; (2) conducting an adequate selection of fish farm sites; (3) designing optimal structures for the area's oceanographic conditions; (4) developing and implementing special technologies and materials to prevent escapes; and (5) preparing more effective procedures and guidelines for the recapture of escaped fish. In this context, the coupling of aquaculture with fisheries (artisanal and recreational) could help manage the natural resources which both of these activities require, and thus the management of escaped salmonids should be addressed accordingly.

Acknowledgements. We thank all those who helped us to compile the information presented in this work, particularly people from the salmon farming industry, academics, Undersecretary of Fisheries (Subsecretaría de Pesca), National Fisheries Service (Servicio Nacional de Pesca, SERNAPESCA), and the Chilean Navy. We also acknowledge P. Moreno, B. Penaluna, and 3 anonymous reviewers for their valuable comments and suggestions in the preparation of this manuscript, and L. Eaton for language corrections. This study was supported by WWF-Chile. 


\section{LITERATURE CITED}

Adey EA, Black KD, Sawyer T, Shimmield TM, Trueman CN (2009) Scale microchemistry as a tool to investigate the origin of wild and farmed Salmo salar. Mar Ecol Prog Ser 390:225-235

Arismendi I (1997) La pesca deportiva en el lago Llanquihue y sus implicancias económicas y ecológicas. Tesis para optar al título de Ingeniero Pesquero, Universidad Austral de Chile, Valdivia

Arismendi I, Nahuelhual L (2007) Non-native salmon and trout recreational fishing in Lake Llanquihue, southern Chile: economic benefits and management implications. Rev Fish Sci 15:311-325

Arismendi I, Soto D, Penaluna B, Jara C, Leal C, LeónMuñoz J (2009) Aquaculture, non-native salmonid invasions and associated declines of native fishes in Northern Patagonian lakes. Freshw Biol 54:1135-1147

Arismendi I, Sanzana J, Soto D (2011a) Seasonal age distributions of introduced resident rainbow trout (Oncorhynchus mykiss Walbaum) reveal lake-inlet fish movements in southern Chile. Ann Limnol Int J Limnol 47:133-140

> Arismendi I, Penaluna B, Soto D (2011b) Body condition indices as a rapid assessment of the abundance of introduced salmonids in oligotrophic lakes of southern Chile. Lake Reservoir Manag 27:61-69

> Arismendi I, González J, Soto D, Penaluna B (2012) Piscivory and diet overlap between two non-native fishes in southern Chile. Austral Ecol 37:346-354

Asche F, Hansen H, Tveteras R, Tveteras S (2010) The salmon disease crisis in Chile. Mar Resour Econ 24:405-411

> Astorga MP, Valenzuela C, Arismendi I, Iriarte JL (2008) Naturalized Chinook salmon in the northern Chilean Patagonia: Do they originate from salmon farming? Rev Biol Mar Oceanogr 43:669-674

Basulto S (2003) El largo viaje de los salmones. Una crónica olvidada. Maval Editorial, Santiago

$>$ Becker LA, Pascual MA, Basso NG (2007) Colonization of the southern Patagonia Ocean by exotic Chinook salmon. Conserv Biol 21:1347-1352

Buschmann AH, Cabello F, Young K, Carvajal J, Varela DA, Henríquez L (2009) Salmon aquaculture and coastal ecosystem health in Chile: analysis of regulations, environmental impacts and bioremediation systems. Ocean Coast Manag 52:243-249

Campos H, Dazarola G, Dyer B, Fuentes L and others (1998) Categorías de conservación de peces nativos de aguas continentales de Chile. Bol Mus Nac Hist Nat (Chile) 47: 101-122

Carpenter S, Frost T, Persson L, Power M, Soto D (1996) Fresh water ecosystems: linkages of complexity and processes. In: Mooney $\mathrm{H}$ (ed) Biodiversity and ecosystem functions: a global perspective. John Wiley \& Sons, New York, NY, p 299-325

Ciancio JE, Pascual MA, Botto F, Frere E, Iribarne O (2008) Trophic relationships of exotic anadromous salmonids in the southern Patagonian Shelf as inferred from stable isotopes. Limnol Oceanogr 53:788-798

Consuegra S, Philllips N, Gajardo G, Garcia de Leaniz C (2011) Winning the invasion roulette: escapes from fish farms increase admixture and facilitate establishment of non-native rainbow trout. Evol Appl 4:660-671

> Correa C, Gross M (2008) Chinook salmon invade southern South America. Biol Invasions 10:615-639

Correa C, Hendry AP (2012) Invasive salmonids and lake order interact in the decline of puye grande Galaxias platei in western Patagonia lakes. Ecol Appl 22:828-842 FAO (Food and Agriculture Organization of the United Nations) (2011) FishSta - fishery statistical collections: aquaculture production. FAO, Rome. Available at www. fao.org/fishery/statistics/en (accessed 15 October 2013)

Fleming IA, Hindar K, Mjølnerød IB, Jonsson B, Balstad T, Lamberg A (2000) Lifetime success and interactions of farm salmon invading a native population. Proc R Soc Lond B Biol Sci 267:1517-1523

Fortt A, Cabello F, Buschmann A (1997) Residuos de tetraciclina y quinilona en peces silvestres en una zona costera donde se desarrolla la acuicultura del salmón en Chile. Rev Chil Infectol 24:14-18

García de Leaniz C, Cajardo C, Consuegra S (2010) From best to pest: changing perspectives on the impact of exotic salmonids in the southern hemisphere. Syst Biodivers 8:447-459

Grosholz ED (2002) Ecological and evolutionary consequences of coastal invasions. Trends Ecol Evol 17:22-27

Habit E, Dyer B, Vila I (2006) Estado de conocimiento de los peces dulceacuícolas de Chile. Gayana (Zool) 70:110-113

Habit E, Piedra P, Ruzzante DE, Walde SJ and others (2010) Changes in the distribution of native fishes in response to introduced species and other anthropogenic effects. Glob Ecol Biogeogr 19:697-710

Jensen Ø, Dempster T, Thorstad EB, Uglem I, Fredheim A (2010) Escapes of fishes from Norwegian sea-cage aquaculture: causes, consequences and prevention. Aquacult Environ Interact 1:71-83

Krkosek M, Lewis MA, Volpe JP (2005) Transmission dynamics of parasitic sea lice from farms to wild salmon. Proc R Soc Lond B Biol Sci 272:689-696

- Marr SM, Marchetti MP, Olden JD, García-Berthou E and others (2010) Freshwater fish introductions in Mediterranean-climate regions: Are there commonalities in the conservation problem? Divers Distrib 16:606-619

- Marr SM, Olden JD, Leprieur F, Arismendi I and others (2013) A global assessment of freshwater fish introductions in Mediterranean-climate regions. Hydrobiologia 719:317-329

Melo T, Rojas P, Pavez P (2005) Evaluación de la posición trófica y la eficiencia de los métodos de recaptura en salmónidos escapados de centros de cultivo. Proyecto FIP 2004-24, Universidad Católica de Valparaíso, Valparaíso. Available at www.fip.cl/Proyectos.aspx (accessed 15 October 2013)

> Moyle PB, Light T (1996) Biological invasions of fresh water: empirical rules and assembly theory. Biol Conserv 78: 149-161

> Naylor R, Hindar K, Fleming IA, Goldburg R and others (2005) Fugitive salmon: assessing the risks of escaped fish from net-pen aquaculture. Bioscience 55:427-437

Niklitschek E, Soto D, Lafon A (2006) Trade liberalization, rural poverty and the environment. A case study of forest and salmon sectors in Chile. The salmon sector. Report CT 05-02. World Wildlife Fund-World Bank, Santiago

Niklitschek EJ, Soto D, Lafon A, Molinet C, Toledo P (2013) Southward expansion of the Chilean salmon industry in the Patagonian Fjords: main environmental challenges. Rev Aquacult 4:1-24

Pascual MA, Lancelotti JL, Ernst B, Ciancio JE, Aedo E, García-Asorey M (2009) Scale, connectivity, and incentives in the introduction and management of non-native species: the case of exotic salmonids in Patagonia. Front Ecol 
Environ 7:533-540

Penaluna B, Arismendi I, Soto D (2009) Evidence of interactive segregation between introduced trout and native fishes in Northern Patagonian Rivers, Chile. Trans Am Fish Soc 138:839-845

Robles R (2002) Análisis de riesgos de la operación de viveros flotantes y barcos de transporte de peces vivos de salmónidos. Proyecto FIP 2002-23, Universidad de Chile, Santiago. Available at www.fip.cl/Proyectos.aspx (accessed 15 October 2013)

Rodríguez Saint-Jean S, Borrego J, Pérez-Prieto S (2003) Infectious pancreatic necrosis virus: biology, pathogenesis and diagnostic methods. Adv Virus Res 62:113-165

Rojas A, Wadsworth S (2007) A review of cage aquaculture: Latin America and the Caribbean. In: Halwart M, Soto D, Arthur JR (eds) Cage aquaculture-regional reviews and global overview. Fish Tech Pap No. 498. FAO, Rome, p 70-100

Schröder V, García de Leaniz C (2011) Discrimination between farmed and free-living invasive salmonids in Chilean Patagonia using stable isotope analysis. Biol Invasions 13:203-213

Sepúlveda M, Oliva D (2005) Interactions between South American sea lions Otaria flavescens (Shaw) and salmon farms in southern Chile. Aquacult Res 36:1062-1068

Sepúlveda M, Farías F, Soto E (2009) Escapes de salmones en chile. Eventos, impactos, mitigación y prevención. WWF, Valdivia

Skilbrei OT, Holst JC, Asplin L, Holm M (2009) Vertical movements of 'escaped' farmed Atlantic salmon (Salmo salar L.) - a simulation study in a western Norwegian fjord. ICES J Mar Sci 66:278-288

Soto D, Guerrero A, Moreno C, Molinet C and others (1997) Evaluación de salmónidos de vida silvestre existentes en las aguas interiores de las Regiones X y XI. Proyecto FIP No. 95-31, Universidad Austral de Chile, Valdivia. Available at www.fip.cl/Proyectos.aspx (accessed 15 October 2013)

Soto D, Jara F, Moreno C (2001) Escaped salmon in the inner seas, southern Chile: facing ecological and social conflicts. Ecol Appl 11:1750-1762

Editorial responsibility: Alejandro Buschmann, Puerto Montt, Chile
Soto D, Arismendi I, González J, Sanzana J and others (2006) Southern Chile, trout and salmon country: invasion patterns and threats for native species. Rev Chil Hist Nat 79:91-117

> Soto D, Arismendi I, Di Prinzio C, Jara F (2007) Recent establishment of Chinook salmon (Oncorhynchus tshawytscha) in Pacific catchments of southern South America and its potential ecosystem implications. Rev Chil Hist Nat 80:81-98

Thorstad EB, Fleming IA, McGinnity P, Soto D, Wennevik $\mathrm{V}$, Whoriskey F (2008) Incidence and impacts of escaped farmed Atlantic salmon Salmo salar in nature. Spec Rep 36. Norwegian Institute for Nature Research, Trondheim

Vanhaecke D, García de Leaniz C, Gajardo G, Thomas CJ, Consuegra S (2012a) Metapopulation dynamics of a diadromous galaxiid fish and potential effects of salmonid aquaculture. Freshw Conserv 57:1241-1252

Vanhaecke D, García de Leaniz C, Gajardo G, Young K and others (2012b) DNA barcoding and microsatellites help species delimitation and hybrid identification in endangered galaxiid fishes. PLoS ONE 7:e32939

> Velásquez JD, L'Huillier G, Hernández L, Rebolledo V, Díaz $M$ (2011) An information system for monitoring the Chilean salmon industry sustainability. Ocean Coast Manag 54:231-240

> Vilata J, Oliva D, Sepúlveda M (2010) The predation of farmed salmon by South American sea lions (Otaria flavescens) in southern Chile. ICES J Mar Sci 67:475-482

> Whoriskey FG, Brooking P, Doucette G, Tinker S, Carr JW (2006) Movements and survival of sonically tagged farmed Atlantic salmon released in Cobscook Bay, Maine, USA. ICES J Mar Sci 63:1218-1223

Young KA, Stephenson J, Tetteau A, Thailly AF, Gajardo G, García de Leaniz C (2009) The diversity of juvenile salmonids does not affect their competitive impact on a native galaxiid. Biol Invasions 11:1955-1961

> Young KA, Dunham JB, Stephenson JF, Terreau A, Thailly AF, Gajardo G, Garcia de Leaniz C (2010) A trial of two trouts: comparing the impacts of rainbow and brown trout on a native galaxiid. Anim Conserv 13:399-410

Submitted: May 3, 2013; Accepted: October 31, 2013

Proofs received from author(s): December 13, 2013 